\title{
Haggai's concern for South Africa: A positive transformation to socio-economic justice as a catalyst for reconciliation
}

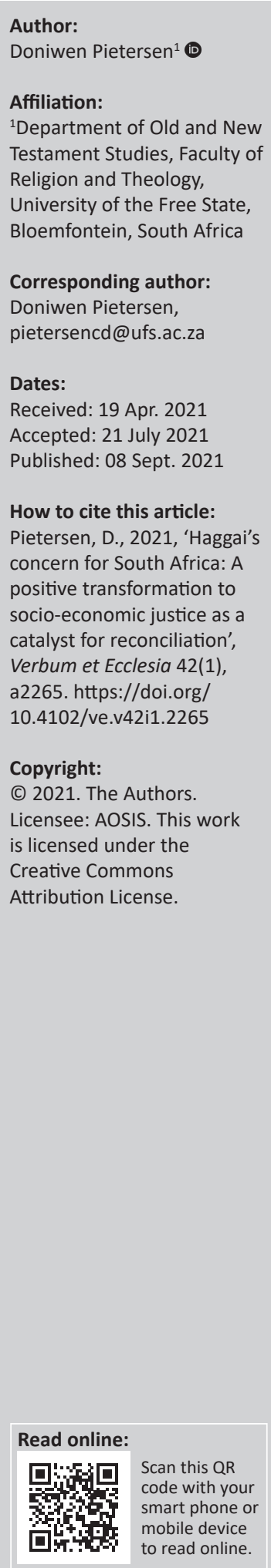

The book of Haggai presents a community where no poverty exists. If העם הזה [his people] obeyed (Ez 6:14), the Lord promised that שלום [prosperity] would follow (Hg 2:19). This command underscores the benefits of living in a covenant relationship with the Hebrew God who bestows provision and blessings on his followers. Such a concept in the ancient Israelite society is a radical one, given the huge disparities that have existed between the rich and the poor for millennia and persist today. This article will explore the theological theme of obedience to God and obligation to others in maintaining an equitable social fabric. Such a discourse is particularly pertinent to South Africa, which suffers from one of the highest levels of inequality in the world. The article employs hermeneutical and socio-historical methods to compare the ancient Israelite society with that of South Africa. This foreground the idea of a catalyst for reconciliation and nation-building.

Intradisciplinary and/or interdisciplinary implications: This article brings theological discourse into discussion with transformational and reconciliation studies, hermeneutic studies, ethical studies as well as practical theology. It also explores the intersections between the texts in the book of Haggai and the context of South Africa with regards to poverty and inequality.

Keywords: Haggai; South Africa; socio-economic justice; positive transformation; reconciliation.

\section{Introduction}

According to Kotzé and Loubser (2019:3), almost 80\% of South Africans profess to belong to the Christian faith. The question is, to what extent should Christians and religion be involved in the reconstruction and reconciliation needed in our country, including addressing the socio-economic injustice aspects? ${ }^{1}$

This article argues that the book of Haggai can provide useful insights that can be guiding principles for addressing the socio-economic inequality in post-apartheid South Africa. ${ }^{2}$ Strauss and De Wet (2014:2-3) propose that a study of this kind where two social contexts are compared would benefit if a hermeneutical lens to view the socio-historical (theological, literary [rhetorical] and social elements) data are used, so that valuable connections and inferences can be made. This approach is grounded on the term of justice which is used more than 19 times in Haggai. Consequently, the author of Haggai implores his audience to demonstrate a unique concern and attentiveness to the poor, helpless and needy (Boloje \& Groenewald 2014:1). In this manner, a 'communitarian ethic' is appropriately framed by the prophets in general', but more so by this prophet in particular (Brueggemann 2001:177; Kessler 2002:100). This article will frame both the ancient Israel and South African context through a socio-historic analysis.

The following steps will be taken in the discussion of the topic. Firstly, a historical background to South Africa's inequality is given, looking at the pre-1994 context. Then, the Natives Land Act number 27 of 1913, the Job Reservation Act number 15 of 1954, and the Bantu Education Act number 47 of $1953^{4}$ will be explored insofar as it gives rise to the vast socio-historic injustices created for

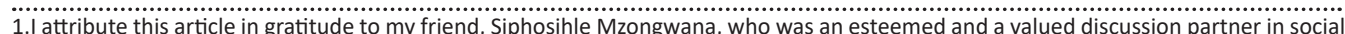
justice from the centre of Old Testament Studies for many years. The article and theme are really based on his convicting justice work.

2.Poverty is thought to have increased for the majority of people in post-apartheid South Africa. Poor people constitute around $61 \%$ of the population, of which $30 \%$ are extremely poor or indigent. It has also been asserted that women are the poorest of the poor revealing a phenomenon known as the 'feminisation of poverty' (Pheko 2019:1).

3.The presence of this prophetic trend reflects larger discourse formulae in other prophetic literature.

4.These acts and their corresponding numbers are listed when referred to throughout the article. 
the South African society. Thereafter, an assessment of the present South African socio-economic situation based on the insights obtained by discussing the book of Haggai is given. Both the Marikana incident and the Fees Must Fall movement are scrutinised in some depth, as well as suggestions for socio-economic upliftment and reconciliation presented in the book of Haggai.

\section{Historical and literary milieu - Haggai}

During the reign of King Cyrus, the Jews were a people that enjoyed better rights than the captives from other nations. He allowed them to re-establish their temple worship and restore their identity. When King Cyrus commanded the rebuilding of the temple, he also ordered the neighbours of the Jews to make generous material contributions towards the building project (Ez 1:4, 6). Cyrus also gave them back the temple goods confiscated by the Babylonian king Nebuchadnezzar (Ez 1:7-9). The Jews themselves gave generously, according to their ability, toward the rebuilding of the temple (Ez 2:69-70) and paid temple workers (Ez 3:7). The Jews found favour with King Cyrus who ensured that they lived comfortably (O'Kennedy 2014:521). His motivation probably was to please all the gods of the nations under his rule so as to enjoy their favour and protection of his kingdom (Baldwin 1972:15). However, the Jews had enemies who opposed them in the land and attempted to hinder them from rebuilding the temple (Ez 4:1-4). Thus, the Jews faced issues from authorities who were colluding against them and discouraging them (Ez 4:5).

During the tyrannical reign of Cyrus' son, King Cambyses, they ceased building the temple and lived in poverty (Baldwin 1972:16; O'Kennedy 2014:525-526). Cambyses was the opposite of his father as he lived in fear of threats to his kingdom (Baldwin 1972:16) and was a 'cruel enemy' to the people of God.

When Darius had succeeded Cambyses as king, they were still impoverished as described in Haggai 1:6-9. The reason given by the prophet is that God was judging them because they were self-indulgent and neglected the Lord's temple. Haggai 1:4 tells us that although they planted much, they harvested little and Haggai 1:9 reads 'you expected much, but see, it turned out to be little'. Then, because of their inaction, Haggai inspired repentance and obedience to the Lord's command. Thus, they enjoyed the Lord's blessing of prosperity (Ez 6:14, $\mathrm{Hg}$ 2:19). Their enemies were to be impaled on a beam if they caused them any trouble or stood in their way (Ez 6:11-12). King Darius provided all their daily needs in order that 'they may offer sacrifices pleasing to the God of heaven and pray for the well-being of the king and his sons' (Ez 6:9-10). Thus, they received full cooperation from their neighbours and authorities and abundant provision even to the extent that they afforded to have a huge dedication feast in celebration of the completion of the temple in king Darius' sixth year (Ez 6:13-18) (Wielenga 2015:1-2).
According to Haggai 1:2-4, the people neglected the house of the Lord. They were preoccupied with their own wellbeing - living life for themselves, building their own homes (panelled or roofed) and not the Lord's. The question in verse 4 is not only about the state of their homes in relation to the Lord's but more to do with what that reflects - the worth and value they ascribed to their Lord if they could leave his house in ruin (Baldwin 1972:40). They disobeyed his command and did not honour him. The Lord told them that their self-indulgence was in vain. That although they earned wages, they soon part with that money means that it is insufficient and does not endure. Investing their hopes in their wages, trusting their money for security, and putting their confidence in their capacity to work do not yield a lasting return. It is also believed that ancient Israel's wealth was not necessarily enjoyed by everyone in the society (Fyall 2010:170-171). This then brings about the comparison to South African society, where also a small number of the population enjoys the largest part of the country's resources. The socio-economic injustice conditions in South Africa can be hold-up against the insights acquired from analysing the book of Haggai.

\section{South Africa's pre-apartheid conditions}

Apartheid was an ideology supported by the Afrikaner National Party which was introduced in South Africa in 1948, although similar discrimination against black people occurred during the preceding rule of the British. Apartheid is described as follows:

'[A]partness', apartheid ... called for the separate development of the different racial groups in South Africa. On paper, it appeared to call for equal development and freedom of cultural expression, but the way it was implemented made this impossible. Apartheid made laws, forced the different racial groups to live separately and develop separately, and grossly unequally too. (SAHO 2016:online)

In short, apartheid was a social system which disadvantaged the majority of the population who lived barely above the poverty line simply because they were classified as 'non-white'.

Based on this definition of apartheid, the discussion focuses on three pieces of racist legislation: the Natives Land Act, introduced under British rule in 1913, the Job Reservation Act of 1954 and the Bantu Education Act of 1953 (Mzongwana 2016:13).

\section{The Natives Land Act number 27 of 1913}

The Natives Land Act, also known as the Bantu Land Act, is a law which was passed in 1913. Its purpose was to distribute land along racial lines, and it remained the basis of apartheid until the 1990s. It prevented the majority of South Africans from land ownership. By preventing African people from buying land and obtaining collateral for access to capital in 
starting businesses, this law led to serious socio-economic inequality:

The fact that so little land was available for African occupation in general meant that large informal settlements, known as squatter settlements, developed in and around most towns and cities. (Mahlangeni 2013:4)

The Natives Land Act was in fact the precursor to another unjust law, the Group Areas Act number 41 of 1950. This act led to well-developed white residential areas and poorly developed black residential areas, which had poor access to water, electricity, sanitation and refuse removal.

If accommodation had to be built for black people under apartheid, it was built some distance away from white residential areas. To legally own land, Africans had to seek permission to occupy land in rural areas and this prevented them from using the land as security for loans for development. Africans could legally reside in the cities and towns only temporarily because they were designated for white people only. 'The Land Act, together with subsequent legislation, effectively reserved $87 \%$ of the country for whites' (Modise \& Mtshiselwa 2013:3). Commenting on the South African land issue, Modise and Mtshiselwa (2013) argue, 'In the South African context, dispossession of land has played and, dare we say, still plays an important role in impoverishing black South Africans'. The examples of the impact dispossession of land has had on many African people who live below the standard of living has been detrimental, the over-populated townships and increased dependence of social welfare to name but a few. This in turn has excluded many from productively taking part in the economies of their 'land'.

The Natives Land Act number 27 of 1913 deprived the majority of black South Africans of the right to productively own land for their economic well-being and sustainability (Modise \& Mtshiselwa 2013:1). Furthermore, Mhlabeni cited in Modise and Mtshiselwa states that 'the National Party government developed the concept of allocating resources such as general infrastructure, education and jobs on a racial basis, and formalised it into law' (Modise \& Mtshiselwa 2013:6). This racial discrimination was taken one step further in the Job Reservation Act.

\section{The Job Reservation Act number 15 of 1954}

According to Alexander et al. (2010:46) the Job Reservation Act of 1954 racially excluded black people from obtaining skilled work. According to this law, better-paid jobs were strictly reserved for white people. This was another way of segregation and to impoverish people further by securing the job market only for white people.

Not only were they barred from certain jobs, but where a black person was allowed to occupy a job not traditionally open to them, the authority and remuneration that accompanied the job were lowered. Referring to the Colour Bar Act of 1926, number 12, Mahlangeni (2013) states:
This legislation ... did to urban Africans what the 1913 Land Act did to rural Africans. It placed an almost absolute barrier to economic advancement for Africans, and advantaged whites by eliminating competition from Africans. (p. 6)

It can be argued that the reason why poverty is so widespread among black South Africans today is because of the institutionalisation of job reservation. It not only excluded black people from skilled and semi-skilled work, but also differentiated the rates of wages between black and white workers who are doing the same job. At the heart of poverty in South Africa lies the inequality and racialisation of income, as well as poor upward mobility in occupations (Viljoen et al. 2013:732). Racial and ethnic identity frequently circumscribed the economic opportunities available to black South Africans during apartheid. Growing income inequality and an erosion of the quality of paid work disproportionately affected those in unstable forms of employment, making them more susceptible to poverty. The next and the final example of apartheid laws to be discussed is the Bantu Education Act.

\section{The Bantu Education Act number 47 of 1953}

While the Natives Land Act prevented black people from owning land and the Job Reservation Act deprived black people from upward job mobility, the Bantu Education Act launched another cruel attack - this time at black youth. Black children were taught:

$[N]$ ot merely the value of their own tribal cultures, but that such cultures were of a lower order and that in general the blacks should learn how to prepare themselves for a realistic place in white-dominated society, namely ... to be 'hewers of wood and carriers of water'. (Christie \& Collins 1982:60)

The gravity of this discrimination is captured in Gool's (1966) statement:

Perhaps the greatest crime that can be inflicted on any people is to strike a blow at its youth - the most defenceless. Bantu education in South Africa does precisely that. The Bantu Education Act ... was designed with only one purpose in view, namely, to deprive the most vulnerable sector of the population - the African child - of obtaining a modern, free, and enlightened education. (p. 1)

Similar in its intentions to the other two pieces of legislation, this act aimed to further white interests to the detriment of black South Africans. These acts were selected to give an overview of the discrimination that existed before 1994. Let us now examine socio-economic inequality in post-1994 South Africa.

\section{South Africa post-apartheid conditions}

When the African National Congress (ANC) won the country's first democratic elections in 1994, expectations ran high that it would reverse the status quo. In the introduction to this article, it was specified that this article would consider 
socio-economic inequality, but more specifically also in relation to poverty. Prevailing poverty should be seen as the background to this section (Amanze 2009:120-121). In order to enrich our examination of contemporary South Africa, two events will now be considered. The first is the Marikana massacre of 16 August 2012 in which 34 miners were shot dead by the police. The second is the \#FeesMustFall movement, a student-led protest which began in 2015 to demand lower fees and greater state funding of universities. Both revealed gaping cracks in the fabric of South African society which deserve further attention (Mzongwana 2016:32-33).

In an abstract, Alexander (2013:605) writes: 'Marikana has revealed structures unseen in normal times'. Later in his article, he recounts issues other than low pay that were likewise not recorded at the time, but that strikers brought up in the interviews. These included the stress of working in hazardous conditions, the arduous nature of their work, difficult production targets, long shifts of 12 hours or more and high levels of disease, such as tuberculosis. White managers were often disrespectful and aggressive. Miners were also under financial strain:

In many cases, workers were caught in a debt trap, leading to forced deductions from wages and payments to micro-lenders and lawyers that left some workers paying 15 times the value of their original loan. (Alexander 2013:607)

Of the \#FeesMustFall movement, similar underlying grievances to the main source of protest can be observed. In discussing the \#RhodesMustFall movement, Badad (2016) argues that the presence of the statue of Cecil John Rhodes at the University of Cape Town (UCT) was offensive to black students. The statue was a:

$[M]$ etaphor for dissatisfaction with a much wider set of issues, expressed in demands related to the 'decolonisation of the university', the highly skewed social composition of the academic work force and especially the professoriate (the dearth of black South African scholars), and institutional culture. (Badad 2016:12)

At Rhodes University in Grahamstown, similar discriminatory themes emerged:

There, 'we can't breathe' was an allusion to a supposedly suffocating institutional culture. The Open Stellenbosch movement added the question of racism more directly, and together with the protesters at the University of Pretoria, that of language policy. (Badad 2016:12)

These events, as Alexander argues, raised an array of other issues that had previously been lying dormant. For example, when the strikes in 2012 spilled beyond the mining industry and reached Western Cape farms, a trade unionist declared: 'Marikana has come to the farms!' (Alexander 2013:610). Both events showed that South Africa has to a certain extent tried to reverse the legacy of apartheid, but the level of inequality in the society proves that many are dissatisfied with the slow pace of change. The cataclysmic upheavals that took place in communities during a time of segregation and bounty for some revealed the things most people choose to ignore in a post-segregated society.
The result of the \#FeesMustFall movement, which involved months of protesting, was 'a dramatic reminder of unfinished business in higher education' (Badad 2016:19). Badad argues that it brought to the fore key issues, such as the 'colonial' mindset of many universities, the lack of black academic staff, the escalation of tuition fees, student debt and the question of free higher education. Although the issues are multi-faceted when it comes to addressing them, the underlining fact is true nonetheless; that the system was setup based on profit-making and excluding many disadvantaged and 'poor' South Africans. This sentiment is captured in the Daily Vox Newspaper (2017):

$[D]$ emanding that education be delivered as a public good, or as a commons, and not as a commodity. In other words, the profit motive must be removed from education delivery. (n.p.)

Commenting on Marikana, Alexander (2013) asserts that the underlying causes of the strike were more fundamental than those which prompted Fees Must Fall:

They are about generalised socio-economic inequalities that have been allowed to persist following the end of apartheid (reflected in the 'rebellion of the poor' as well as rebellion among workers). (p. 615)

Likewise, Badad comments as follows on Fees Must Fall: 'For education to become more equitable and contribute effectively to social justice in South Africa ${ }^{5}$, there have to be bold and purposeful social justice-oriented policies and initiatives in other arenas of society'.

As noted before, the ANC government's post-1994 economic policies have not been orientated towards fundamentally addressing inequality, even if there have been some pro-poor social policies geared towards addressing certain dimensions of poverty (Badad 2016:8-9). In fact, it would be fair to say that the problems the ANC government inherited from the colonial era and apartheid have not been fully resolved. As Modise and Mtshiselwa (2013) contend:

One would suspect that the legacy of socio-economic injustice which was possibly inherited from the Natives Land Act number 27 of 1913 continues to haunt the majority of black South Africans. Although we may not appreciate such a suspicion, the fact that an estimated $4.35 \%$ of white people are poor, compared to $61.4 \%$ of black South Africans (Stats SA 2019:71) points to the direction of our suspicion. The challenge of poverty is a disturbing reality in South Africa. (p. 1)

\section{The book of Haggai vis-a-vis socio-economic conditions in South Africa}

The above discussion shows that socio-economic inequality in South Africa remains a pernicious problem. This section

5.The recent COVID-19 crisis has precipitated a financial disaster in many global colicies and laissez-faire economics. South Africa is no exception. For the most part, the expectation that market efficiency would accompany deregulation and channe investment where it is most needed, has not come to pass. Poverty reduction, higher employment rates and more equitable income distribution have so far proved elusive for most South Africans. These issues are connected, but an in-depth discussion is beyond the scope of this article. 
will use the book of Haggai ${ }^{6}$ to make sense of the socioeconomic conditions in South Africa as a pathway to understand positive reconciliation. To begin with, let us firstly consider the historical background of the account of Haggai.

On the first day of the sixth month in the second year of King Darius, חגי הנביא (Haggai) ${ }^{7}$ became the first post-exilic prophet to speak a word from the Lord to the Israelites. After Persia defeated Babylon, the Israelites were allowed to return to Judah. There they commenced rebuilding the temple after the Lord God charged the then Persian King Cyrus to command them to do so (Wielenga 2015:2). After they completed the laying of the foundation, their enemies made every effort to frustrate their plans throughout King Cyrus' reign and into the reign of King Darius (Ez 4:5) (Assis 2008:4). The Israelites were presumably disheartened and thus ceased rebuilding the temple. We are, however, given the reason why they ceased working in Haggai 1:2-6: they failed to obey God's command to rebuild the temple, and choosing instead to preoccupy themselves with their own houses and livelihood. Some ${ }^{8}$ may argue that the meaning of הבית [house] here is by no means self-evident in its interpretation of how people treat YHWH's house or their own houses. Therefore, for the purpose of this article my interpretation is based on the crux interpretum principle. This is to say that the interpretation can refer to both God's הבית and the people hoarding material for their own houses in the process. This negative expression here gives both the sense of disdain and a sense of judgement from YHWH (Kessler 2002:137; Meyers \& Meyers 1987:42-43). There is also the undeniable argument of language at play here; the use of הבית referring to the homes of the people are marked with intermittent pronominal suffixes (e.g. Chapter 1 v. בבתיכם 4 בin your houses'), whereas the many other occurrences do not have this.

The prophet Haggai was then sent by ${ }^{10}$ the Lord to convict the Israelites of their disobedience and rouse them to complete the task set before them (Swinburnson 2008:28-46).

During the tyrannical reign of Cyrus' son, King Cambyses, the Israelites had stopped building the temple and lived in poverty (Baldwin 1972:16). Cambyses was the opposite of his father as he lived in fear ${ }^{11}$ of threats to his kingdom and was

6.The English Standard Version (ESV), the Biblia Hebraica Stuttgartensia (BHS) and the transliteration of the BHS were utilised.

7. Here Haggai is made known to the people of YHWH as a spokesperson: 'Haggai the prophet'. This title is used four times in the narrative $(1: 3,12 ; 2: 1,10)$, although one prophet'. This title is used four times in the narrative $(1: 3,12 ; 2: 1,10)$, although one
may argue that three times he is called simply 'Haggai' $(2: 13,14,20)$ or, once in may argue that three times he is called simply 'Haggai' $(2: 13,14,20)$ or, once in
$1: 13$, 'the messenger of $Y H W H$ '. This is not a title anyone would aspire to because he $1: 13$, 'the messenger of YHWH'. This is not a title anyone would aspire to because he
needs to fulfil the social role 'with real status' and thus an 'authority and dignity' needs to fulfil the social role 'with real status' and thus an 'authority and dignity'
(Kessler 2002:118). This is to allow positive socio-economic reforms that may lead to true reconciliation for Yahweh's people coming out of exile.

8.See, Petersen (1984:52) for the in-depth discussion on the textual ambiguity at this juncture.

9.Cf. Haggai 2.11-14, Malachi 1 for how YHWH as a subject is treated in the text.

10.This is marked by a four-pattern oracle that looks like this; 'Then you will know that YHWH of hosts has sent me to you' (וידעתם כי יהוה צבאות שלחני אליכם) (Petersen 1984:178)

11. מפני + ירא generally means 'to be afraid of', not 'to fear' in the reverential sense which gives the impression that the people were more afraid of an enemy of God than God himself. a 'cruel enemy' to the people of God (Calvin 1986:320). When Darius succeeded Cambyses as king, the Israelites were still impoverished, as described in Haggai 1:6-9. The reason given in Haggai is that God was judging his people because they were self-indulgent and neglected the Lord's temple. Haggai 1:4 tells us that although the Israelites planted much, they harvested little. Haggai 1:9 reads: 'you expected much, but see, it turned out to be little ${ }^{\prime 2}$. Because of their subsequent repentance and obedience to the Lord's command, they enjoyed the Lord's blessing and prosperity (Ez 6:14, $\mathrm{Hg}$ 2:19). Their enemies were to be impaled on a beam if they caused them any trouble or stood in their way (Ez 6:11-12). King Darius provided all their daily needs in order that 'they may offer sacrifices pleasing to the God of heaven and pray for the שלום [well-being] of the king and his sons' (Ez 6:9-10). Thus, they had full cooperation from their neighbours and authorities and abundant provision, even to the extent that they could afford to have a huge dedication feast in celebration of the completion of the temple (Ez 6:13-18).

Later, during the reign of King Artaxerxes, Israel's enemies convinced the king that Jerusalem posed a threat to his kingdom. They persuaded him that the Israelites would, in honour of their God, rebel against him and refuse to pay taxes and tributes. As a result, King Artaxerxes decreed that the rebuilding of Jerusalem should cease (Ez 4:11-22). Under his reign, the Israelites intermarried (Ez 9-10), and suffered economic hardship, debilitating taxes and harsh treatment by the authorities (Neh 5:4-16).

According to Haggai 1:2-4, the people neglected 'the house of YHWH' (להביא בית יהוה), the house of the Lord. They were preoccupied with their own well-being by living life for themselves, completing the building of their own ספונים (panelled) or roofed homes and not the Lord's ${ }^{13}$. The question in verse 4 is not only about the state of their homes in relation to the Lord's, but what that reflects: the worth and value they ascribed to the Hebrew God if they could leave his house in ruins (Baldwin 1972:40; Meyers \& Meyers 1987:23). They disobeyed his command and did not honour him. The Lord told them that their self-indulgence was in vain. Although they earned wages, they would soon part with their money. Investing their hopes in their wages, trusting their money for security and putting their confidence in their capacity to work would not yield a lasting return. Despite their toil, they lacked food, clothes, money and crops ( $\mathrm{Hg} 1: 6)$.

The Lord proved to them the futility of their hard work when they failed to trust and obey him (Merrill 2003:37). He explained to them the true reason for their impoverishment at the end of verse 9:

12.The verb פנה suggests here that $\mathrm{YHW}$ in is the subject here. This indicates the tone at which the people are to respond to him (Lv 26.9, Jdg 6.14, 2 Ki 13.23, Ezek 36.9, cf. Ps $25: 16 ; 69: 17 ; 86: 16 ; 119: 132$ ).

13.See Walton, Mathews and Chavalas (2000:15) who argue that 'panelled' can mean covered or roofed, suggesting that their homes were not newly started, but were completed; they were adding finishing touches to their homes, while the Lord's house remained a ruin. This does not imply that they were building expensive houses, even though wood panelling could be perceived as an expensive luxury. Wood panelling was uncommon for people with status, even though Solomon's Wood panelling was uncomm
house was panelled (1 Ki 7:7). 
You expected much, but see, it turned out to be little. What you brought home; I blew away. Why? ... Because of my house, which remains a ruin, while each of you is busy with his own house. ( $\operatorname{Hg} 1: 9-11)$

They forgot the God of Israel's command to seek his ultimate pleasure in their work ( $\mathrm{Hg} 1: 8)$. As a result, the Lord was displeased with them and withheld his blessings from them. He called for a סֶרב [drought] on the fields and caused the earth to withhold its crops. The words for drought and ruin sound similar in the original Hebrew. This similarity is played on in the text to draw a connection between the ruin of the Lord's house and the drought faced by the Jews. In other words, this link emphasises the point that the drought was retribution for the ruin of God's temple (Baldwin 1972:42). It is because of this that the Lord says to the Israelites [Give careful thought to your ways], twice in the same chapter $(\operatorname{Hg} 1: 5,7)^{14}$.

So the God of Israel instructed them to rebuild ${ }^{15}$ his house. When they did so and followed his instructions, the Lord lifted his judgement on them and blessed them. Devotion to one's own house to the neglect of the house of the Lord led to judgement, while devotion to the house of the Lord led to blessing.

Let us now examine how the Israelite society in the book of Haggai compares with the post-apartheid South Africa. Israel was engaged in a process of constituting a new society and began to take on a new identity (Wittenberg 2009:89). In much the same way, after 1994 South Africa was also engaged in a process of constituting a new society and becoming a rainbow nation which aimed to celebrate ethnic diversity. Wittenberg argues that in ancient Israel and Judah, constituting a new social identity almost always caused a social crisis that eventually undermined the fabric of the free peasant community. This kind of ideology was to some extent embraced, but also condemned in many ways by Amos, Micah and Isaiah. By the beginning of Josiah's reign, it had reached an advanced stage.

However, 'the reformers were intent on finally putting a stop to the disastrous deterioration of the social situation of the poorer members of the peasant community' (Wittenberg 2009:94). Brueggemann notices that the resolve in the book of Haggai for there to be no more 'permanent underclass that is hopelessly and perpetually in debt' is radical and crucial 'in the larger pattern of the "sabbatical principle"16 of Israel's social ethic'. He also notes that 'it is a contradiction of the more conventional economic assumptions and practices that recur in every society' (Brueggemann 2001:168). As Badad

14.The composer contends that Israel ought to "take note of' their corruption and change their attitude in order to encompass the prosperity of the whole community (see also Job 1:8; 2:3 for similar references). Here Haggai shares many parallels to how South Africa can positively engage its people to share in the country's wealth in order to bring about reconciliation.

15. Haggai plays his socio-political role in brilliant oratorical persuasion when he appeals to his people in prophetic ethos - that is to say, the people of YHWH suffered unnecessarily by neglecting the reconstruction of the temple.

16.This indicates a 'new policy directive' to convince the people why the rebuilding of the temple is important - much like electioneering in modern-day society. has already indicated above, South Africa perhaps needs to take a cue from the book of Haggai and make resolutions that are both radical and crucial to deal with the debilitating socio-economic inequality.

\section{Liberation from debt and slavery}

It is important that we understand the theological basis for the stand that the book of Haggai takes. Firstly, Israel is reminded that as people of the covenant, they are all brothers and sisters. The text does away with the designations of debtor/creditor, slave/master and man/woman and replaces them with brother and sister. How people categorise themselves has a bearing on how they treat one another. With racial distinctions so deeply entrenched in South Africa, this theological understanding can be of great help in liberating distinctions between different socio-economic classes. It can also help in instilling a sense of generosity. Secondly, just as God liberated Israel from Egypt, human beings have an obligation to liberate their brothers and sisters who are indebted and enslaved to them.

It could be argued that there is a profound contradiction at work when the followers of a liberating God are themselves indebted and enslaved. It is the duty of those who serve God to liberate their brothers and sisters who are enslaved to debt. From the time of British colonialism to apartheid, different sectors of South African society have been forced into subjugation of some sort and then been liberated from it, although often psychological scars remain. As the book of Haggai suggests, the Israelites have an obligation to release their fellow human beings who, for whatever reason, are trapped (Schwarz 2000:152-161). Lastly, Haggai bases its stance on debts and slaves on the blessing that God bestowed and continues to bestow on the covenant community.

A remarkable observation is made by Crüsemann. He asserts that in Haggai, blessing which was expected to come from participating in worship, is attached to observing social laws (Crüsemann 1996:225-226). The notion of blessing that Crüsemann highlights here speaks to how blessing was misunderstood, and actually should be understood not only vertically (blessing as the work of God on his obedient people) but also horizontally (when we act justly towards other people it leads to a state of blessedness instead of cursedness). In fact, the book of Haggai emphasises these social laws. Interpreting the theme of blessing, McConville (2002) argues that the book of Haggai is not only promoting welfare as such, but rather encouraging all members of the Israelite community to participate fully in the enjoyment of God's blessing so that they may move toward a positive sense of reconciliation, given their experience in exile. People of faith in South Africa, from all quarters, need to be enlightened about this principle in their poverty-alleviation efforts.

\section{A promise to restore the temple's glory}

About a month after rebuilding the temple had started, during the Feast of Tabernacles (Verhoef 1987:92), the Lord 
spoke a second time to Haggai. He gave Haggai words with which to uplift שלתיאל [Zerubbabel], the governor of Judah, Joshua the high priest and the Israelites. Knowing his people would be discouraged by the shabbiness of the temple and their lack of resources, the Lord exhorts them to finish their work. At this early stage, the little that had been built had the potential to dishearten the Israelites. The mere foundation, when completed, was enough to reduce the elder statesmen to tears when they reflected on the former splendour of the העם הזה [temple] ${ }^{17}$, while others celebrated (Ez 3:12-13). It would be bigger than Solomon's original structure, but void of its treasures and craftsmanship, and it didn't 'comply with the promises of the earlier prophets for the grand renovation in the messianic age' (Verhoef 1987:96-97) Also, the Israelites would have been slowed down by the painstaking labour of getting rid of the rubble that had stood there for 60 years and by the frequent breaks caused by religious holidays (Verhoef 1987:92). A final source of discouragement was the lack of resources to continue.

In order to lift the spirits of his people and keep them steadfast, the Lord paints a picture of the future temple that will surpass its old glory and assures them that he will provide the means to finish the job. This is the immediate context of Haggai 2:3-9. This text explains that the basis of the hope of a temple filled with this surpassing glory is the Lord's provision (Japhet 1991:207-217). It is helpful to note that what is being compared is the future glory versus the former glory of the same temple (Gelston 2010:131).

Despite its destruction and rebuilding, the temple has a 'continuous existence' that varies in glory (Verhoef 1987:105). Now the Lord promises that he 'will once more shake the heavens and the earth... shake all nations, and what is desired by all nations will come' and that his כבוד [glory] will fill his house ( $\mathrm{Hg}$ 2:6-7). Shaking the heavens and the earth and all the nations implies the Lord's intervention and seems to indicate 'that men are thus powerfully, and in an extraordinary or supernatural manner influenced, so that they follow spontaneously at the same time' (Calvin 1986:359) because after his intervention will be the coming of the 'desired of all nations'. The Hebrew word for 'desired' is plural and is better translated as 'desirable things'. It is therefore improbable that the interpretation of this word is a reference to the coming of Christ (Fyall 2010:170-171). This word 'desired', denotes valuable things, treasures, things which are precious (Calvin 1986:360) and so the best rendering of verse 7 is that the Lord will move the nations to bring to the temple precious valuables. This is supported by the following verse, which functions simultaneously as the assurance that this is possible and the reason why it will happen: 'The silver is mine and the gold is mine', declares the Lord Almighty' (Hg 2:8). Jacobs (2017:90-91) writes, 'Perhaps Haggai 2:8 illustrates what the treasure entails. The silver is

17.This word reflects not only a misguided people that has gone wrong in their appraisal of this building, but also indicates a sense of how wayward the building is and how that also signifies a waywardness in the hearts of 'this people'. mine, and the gold is mine'. Again, this expression of the treasures returned to the exiles, that is, silver and gold (kesep wazāhāb) mainly refers to what belongs to YHWH (cf. $\mathrm{Hg}$ 2:3). Given the time this expression came about, it is evident that $\mathrm{YHWH}$ is very concerned about the positive changes in the socio-economic conditions of his exiles in order that they may move homeward (Jerusalem) and at the same time achieve true physical and mental reconciliation (Petersen 1984:69).

In summary, the Lord is urging his people to take heart and continue building. He assures the Israelites that all the gold and silver in the world is his and will be used for his glory, and that he will act decisively and cause the nations to bring it to his people. He promises that the gold, silver and other precious valuables with which his house will be filled will be far more glorious than in the past. This is partially fulfilled when King Darius secures for the Jews the support of even their enemies and places at their disposal the resources needed for the beautification of the temple (Ez 6:9-10). It is also partially fulfilled later in Herod's and his successors' reign when the temple is even more extravagantly lavished with wealth and glory (Baldwin 1972:48).

It could be argued that the meat concealment passage $(\mathrm{Hg} 2: 12-23)$ is the underlying message of the book. Consecrated meat could not consecrate unclean things by touch because 'the flesh itself was not dedicated to God for this end', just as an unclean man makes unclean that which he touches (Calvin 1986:369). Verse 14 establishes the uncleanness of the תרומה נדבה [offerings] of the Israelites because they themselves were defiled, presumably by their unrepentant neglect of the temple rebuilding project (Wolf 1976:9). YHWH is not satisfied because the best of the offerings are withheld for personal use ${ }^{18}$.

Haggai exhorts the Israelites to repent. His core מלאכות [commissioned message] is for the Israelites to return to God so that he will bless them and they will escape judgement and punishment (Redditt 2007:188-195). This message is underscored by the expression, 'Give careful thought to your ways', which like a leitmotif appears five times in the book (chs. 1:5, 7, 2:15, 18 and 18) and three times in this chapter alone in varied ways. The repetition of this phrase emphasises its overarching significance in the book. The prophet urges the Israelites to reflect on their behaviour and then details the benefits or disadvantages which will result from their actions.

Unlike chapter 1:3-11, which ends in judgement following Israel's disobedience, this passage ( $\mathrm{Hg} 2: 10-15)$ ends with the promise of the Lord's blessing following Israel's obedience in rebuilding the temple. Even though there is no seed in the Israelites' barns or fruit left on their trees, the Lord undertakes to reverse this poverty in verse 19 by saying, 'From this day on, I will bless you'.

18.The word הצר acting as a verb in this context of YH HW's refusal can mean 'to be pleased with' (BDB 1907:953), but YHWH is not pleased with it, because the same pleased with' (BDB 1907:953), but YHWH is not pleased with it, because the same
word רצn can also render a distinct cultic use of 'acceptance on the part of the word רצn can also render a distinct cultic
receiver' and YHWH will have none of it. 


\section{Conclusion}

The book of Haggai can help us formulate an approach that addresses socio-economic inequality in South Africa and achieve reconciliation in a positive form. The answer lies in taking seriously the themes of brotherhood and blessing, notwithstanding the irrefutable undercurrent of the urgency of rebuilding and restoring a true sense of community that runs throughout Haggai and the post-exilic prophets as a whole. As with the ancient Israelites in Haggai, the only way the people of South-Africa will flourish as a community is by means of a positive attitude towards transformation and socio-economic justice, which it is expected will accelerate the pace of racial reconciliation. In embracing these themes, we need to emphasise their social ramifications, without abandoning their religious implications. The book of Haggai serves as a reminder that the Hebrew God who freed Israel from Egypt is a liberating God, and so in turn human beings need to liberate others. Haggai proposed a model of prosperity for ancient Israel. In the same way, it is believed that a positive attitude to socio-economic justice can serve as a catalyst for reconciliation and nation-building in South Africa.

\section{Acknowledgements Competing interests}

The author declares that they have no financial or personal relationships that may have inappropriately influenced them in writing this article.

\section{Author's contributions}

D.P. is the sole author of this article.

\section{Ethical considerations}

This article followed all ethical standards for research without direct contact with human or animal subjects.

\section{Funding information}

This research received no specific grant from any funding agency in the public, commercial or not-for-profit sectors.

\section{Data availability}

Data sharing is not applicable to this article as no new data were created or analysed in this study.

\section{Disclaimer}

The views and opinions expressed in this article are those of the author and do not necessarily reflect the official policy or position of any affiliated agency of the author.

\section{References}

Alexander, G., Van Wyk, M.M., Bereng, T. \& November, I., 2010, 'Legitimate periphera participation (LPP) - The case for recognition of prior learning sites and knowledges in South Africa's transforming education system', Teaching and Teacher Education 26(1), 45-52. https://doi.org/10.1016/j.tate.2009.06.012
Alexander, P., 2013, 'Marikana, turning point in South African history', Review of African Political Economy 40(138), 605-619. https://doi.org/10.1080/03056244.2 013.860893

Amanze, J.N., 2009, 'Paradigm shift in theological education in Southern and Central Africa and its relevance to Ministerial formation', International Review of Mission 98(1), 120-131. https://doi.org/10.1111/j.1758-6631.2009.00010.x

Assis, E., 2008, 'The temple in the book of Haggai', Journal of Hebrew Scriptures 8 , a19. https://doi.org/10.5508/jhs.2008.v8.a19

Badad, S., 2016, Deciphering the meanings, and explaining the South African higher education student protests of 2015-2016, viewed 20 October 2020, from http:// wiser.wits.ac.za/system/files/documents/Saleem $\% 20$ Badat $\% 20 \% 20$ Deciphering $\% 20$ the $\% 20$ Meanings, $\% 20$ and $\% 20$ Explaining $\% 20$ the $\% 20$ South $\% 20$ African $\% 20$ Higher $\% 20$ Education $\% 2$ Student $\% 2$ Protests.pdf.

Baldwin, J., 1972, Tyndale Old Testament commentaries: Haggai, Zechariah and Malachi, IVP, Downers Grove, IL.

Bọlọe, B.O. \& Groenewald, A., 2014, 'Malachi's concern for social justice: Malachi 2:17 and 3:5 and its ethical imperatives for faith communities', HTS Teologiese Studies/Theological Studies 70(1), 1-9. https://doi.org/10.4102/hts.v70i1.2072

Brown, F., Driver, S.R. \& Briggs, C.A., 1907, A Hebrew and English Lexicon of the Old Testament, Oxford University Press, Oxford.

Brueggemann, W., 2001, Deuteronomy, Abingdon Press, Nashville, TN.

Calvin, J., 1986, The minor prophets volume 4: Habakkuk, Zephaniah \& Haggai, The banner of Truth Trust, Carlisle, PA.

Christie, P. \& Collins, C., 1982, 'Bantu education: Apartheid labour reproduction?', Comparative Education 18(1), 59-75. https://doi.org/10.1080/0305006820180107

Fyall, R., 2010, The message of Ezra and Haggai, IVP, Norton Street.

Gelston, A., 2010, Biblia Hebraica Quinta, XIII: The twelve minor prophets, Deutsche Bibelgesellschaft, Stuttgart.

Gool, J., 1966, The crimes of Bantu education in South Africa, Unity Movement Publication, Lusaka.

Hoppe, L.J., 2004, There shall be no poor among you: Poverty in the Bible, Abingdon Press, Nashville, TN.

Jacobs, M.R., 2017, The books of Haggai and Malachi, William B. Eerdmans Publishing Company, Grand Rapids, Ml.

Japhet, S., 1991, 'The temple in the restoration period: Reality and ideology', Quarterly Review 44, 195-251.

Kessler, J., 2014, The Book of Haggai: Prophecy and society in Early Persian Yehud, Leiden, Netherlands, Brill.

Kotzé, H. \& Loubser, R., 2019, 'Religiosity in South Africa: Trends among the public and elites', Scriptura 116(1), 1-12. https://doi.org/10.7833/116-1-1287

Mahlangeni, B.M., 2013, 'Reflections on the impact of the Native's Land Act, 1913, on Local Government in South Africa in White Paper on Local Government (1998)', Government's policy framework for the transformation of Local Government, Pretoria, viewed 05 November 2019, from http://www.parliament.gov.za/content/ Land\%20Act $\% 20 \% 20$ Paper\%203\%20-\%20Langa\%20-\%20Final.pdf.

McConville, J.G., 2002, Deuteronomy, Apollos, Leicester.

Merrill, E.H., 2003, Haggai, Zechariah, Malachi: An exegetical commentary, Biblical Studies Press, Grand Rapids, MI.

Meyers, C.L. \& Meyers, E.M., 1987, Haggai, Zechariah 1-8, Doubleday, Garden City, NY.

Modise, L. \& Mtshiselwa, N., 2013, 'The Natives Land Act of 1913 engineered the poverty of black South Africans: A Historico - Ecclesiastical perspective', a paper read at the conference of the theological society of South Africa (TSSA) in Cape Town, South Africa, June 2013, 1-20, TSSA.

Mzongwana, S., 2016, 'A theological - Ethical analysis of Deuteronomy 15: A contribution to the socio-economic inequality discourse in South Africa' Unpublished thesis, Stellenbosch University.

O'Kennedy, D.F., 2014, 'Haggai 2:20-23: Call to rebellion or eschatological expectation?', Old Testament Essays 27(2), 520-540.

Petersen, D.L., 1984, Haggai and Zechariah 1-8, John Knox Press, Westminster.

Redditt, P.L., 2007, 'Themes in Haggai-Zechariah-Malachi', Interpretation 61(2), 184-197. https://doi.org/10.1177/002096430706100206

Pheko, L., 2019, 'Race, gender and class: Tensions and contradictions of intersectionality', Paper to University of South Africa Symposium, s.n., s.l.

Stats S.A., 2019, Inequality trends in South Africa: A multidimensional diagnostic of inequality, Statistics South Africa, Pretoria.

Schwarz, H., 2000, Eschatology, Eerdmans, Grand Rapids, MI.

South African History Online (SAHO), 2016, A history of apartheid in South Africa, viewed 12 October 2017, from http://www.sahistory.org.za/article/historyapartheid-south-africa.

Strauss, H.S.W. \& De Wet, F.W., 2014, 'Hermeneutiese uitdagings aan Christocentrische prediking vanuit die Ou-Testamentiese narratiewe', In die Skriflig/In Luce Verbi 4(8), 1-20. https://doi.org/10.4102/ids.v48i2.1717

Swinburnson, B.W., 2008, 'The glory of the latter temple: A structural and biblicaltheological analysis of Haggai 2:1-9', Kerux 2(3), 28-46.

The Daily Vox, 2017, We asked academics to weigh in on the \#FeesMustFall debate, viewed 01 September 2019, from https://www.thedailyvox.co.za/askedacademics-weigh-feesmustfall-debate.

Verhoef, P.A., 1987, The New International commentary on the Old Testament: The books of Haggai and Malachi, Wm. B. Eerdmans Publishing, Grand Rapids, MI. 
Viljoen, D. \& Sekhampu, T.J., 2013, 'The impact of apartheid on urban poverty in South Africa: What we can learn from history', Mediterranean Journal of Social Sciences 4(2), 729-734.
Scith Africa: What

Walton, J.H. \& Matthews, V.H., 1997, The IVP Bible background commentary: Genesis Deuteronomy, IVP, Downers Grove, IL. Walton, J.H., Mathews, V.H. \& Chavalas, M., 2000, Bible background commentary, IVP,
Downers Grove,
Wielenga, B., 2015, 'Eschatological hope in Haggai: A homiletic reading', In die Skriflig/ In Luce Verbi 49(1), 1-13. https://doi.org/10.4102/ids.v49i1.1820

Wittenberg, G., 2009, 'The Tithe - An obligation for Christians? Perspectives from Deuteronomy', Journal of Theology for Southern Africa 13(4), 83-101.

Wolf, H., 1976, 'The desire of all nations in Haggai 2:7: Messianic of not?', Journal of the Evangelical Theological Society 1(9), 97-102. 